\title{
PEMANFAATAN LIMBAH KULIT PISANG SEBAGAI PUPUK ORGANIK CAIR DAN APLIKASINYA TERHADAP PERTUMBUHAN TANAMAN KANGKUNG DARAT(Ipomea reptans Poir)
}

\author{
Utilization of Banana Peel Waste as an Organic Liquid Fertilizer and its Aplication on Growth \\ of Swamp Cabbage Land (Ipomea reptans Poir)
}

\author{
*Ince Manis, Supriadi, dan Irwan Said \\ Pendidikan Kimia/FKIP - Universitas Tadulako, Palu - Indonesia 94118 \\ Received 11 September 2017, Revised 10 October 2017, Accepted 10 November 2017
}

\begin{abstract}
Banana peel waste utilization as organic manure and its application has been made to the land kale plant growth (Ipomea reptans poir). This paper aims to describe how to manufacture liquid organic fertilizer from waste banana skin, determine the total nitrogen content of liquid organic fertilizer and the effect of liquid organic fertilizer waste banana skin on plant growth kale land (Ipomea reptans poir). The method used was experimental at the stage of making a liquid organic fertilizer waste banana peel in fermentation, the determination of total nitrogen content and the application of the organic liquid fertilizer waste banana skin using a randomized block design (RBD) with 4 treatments include PO $(0 \mathrm{~mL}) ;$ P1 $(20 \mathrm{~mL}) ;$ P2 (40 mL); and P3 $(60 \mathrm{~mL})$. The parameters measured were plant height $(\mathrm{cm})$, number of leaves (leaf) and wet weight $(\mathrm{g})$. The growth data of the swamp cabbage land (Ipomea reptans poir) were analyzed by using the statistical test analysis of variance (ANOVA) then followed by Duncan test with significance level of $5 \%$. The results showed that levels of total nitrogen of the organic liquid fertilizer waste was $0.032 \%$ and the application of the organic liquid fertilizer of banana peel waste on the growth of swamp cabbange land (Ipomea reptans poir) influence on plant height (cm) and wet weight (g) but have no effect on the number of leaves (leaf). Treatment P2 $(40 \mathrm{~mL})$ showed the best result for the average plant height (cm), number of leaves (leaf) and wet weight (g) of the swamp cabbage land (Ipomea reptans poir).
\end{abstract}

Keywords: Banana peel waste, liquid organic fertilizer, kale land (Ipomea reptains Poir)

\section{Pendahuluan}

Sayuran merupakan salah satu komoditas penting dalam mendukung ketahanan pangan nasional. Komoditas ini memiliki keragaman yang luas. Produksi sayuran Indonesia meningkat setiap tahun dan konsumsinya tercatat 44 $\mathrm{kg} / \mathrm{kapita} /$ tahun sehingga permintaan sayuran akan terus meningkat seiring dengan bertambahnya jumlah penduduk (Ohorella, 2012). Oleh karena itu, sektor pertanian terutama hortikultura khususnya sayuran mempunyai peluang yangbesar untuk memenuhi salah satu kebutuhan pangan sebagai sumber vitamin, mineral dan serat yang diperlukan untuk kesehatan tubuh dan untuk meningkatkan kualitas sumber daya manusia (Taufika, dkk., 2011)

Kangkung darat (Ipomoea reptans poir.) merupakan salah satu jenis tanaman sayuran yang tergolong dalam Famili Convolvulaceae dan banyak digemari oleh seluruh lapisan masyarakat (Wijaya, dkk., 2014). Sayuran ini memiliki rasa yang renyah dan kaya akan sumber gizi yakni protein, lemak, karbohidrat, $\mathrm{P}, \mathrm{Fe}$, vitamin $\mathrm{A}$, dan

${ }^{*}$ Correpondence

Ince Manis

Program Studi Pendidikan Kimia, Fakultas Keguruan dan IImu Pendidikan, Universitas Tadulako

e-mail: ince.maines@gmail.com

Published by Universitas Tadulako 2017
B yang penting bagi kesehatan tubuh (Moerhasrianto, 2011)

Meningkatnya permintaan masyarakat terhadap kangkung darat membuat sayuran ini banyak beredar dipasar lokal dan harganya pun relatif murah dibandingkan jenis sayuran lain. Para petani melakukan upaya untuk memenuhi kebutuhan konsumen, baik dalam segi kualitas maupun kuantitas (Fahrudin, 2009). Salah satu upaya peningkatan hasil yang dapat dilakukan adalah melalui pemupukan.

Selama ini para petani masih menggunakan pupuk kimia dalam membudidayakan kangkung darat (Ipomoea reptans poir). Hal ini dikarenakan pupuk kimia relatif lebih mudah didapatkan di pasaran namun demikian harganya relatif mahal dan kurang ramah lingkungan (Dewanto, dkk., 2013). Penggunaan pupuk kimia dalam jangka relatif lama terbukti telah menimbulkan masalah serius, antara lain pencemaran tanah dan air, penurunan tingkat kesuburan tanah, dan ketergantungan petani secara ekonomi dan social (Sedayu, dkk., 2014). Penggunaan pupuk kimia juga memiliki dampak berbahaya terhadap kesehatan manusia (Mahmoud, dkk., 2009). Oleh sebab itu, diperlukan budidaya kangkung darat secara organik dengan mengunakan pupuk organik cair.

Pupuk organik cair adalah pupuk yang bahan dasarnya berasal dari hewan atau tumbuhan yang sudah mengalami fermentasi berupa cairan dan 
kandungan bahan kimia di dalamnya maksimum 5\%. Pada dasarnya pupuk organik cair lebih baik dibandingkan dengan pupuk organik padat. Hal inidisebabkan penggunaan pupuk organik cair memiliki beberapa kelebihan yaitu pengaplikasiannya lebih mudah, unsur hara yang terdapat di dalam pupuk cair mudah diserap tanaman, mengandung mikroorganisme yang banyak, mengatasi defesiensi hara, tidak bermasalah dalam pencucian hara, mampu menyediakan hara secara cepat, proses pembuatannya memerlukan waktu yang lebih cepat, serta penerapannya mudah di pertanian yakni tinggal disemprotkan ke tanaman (Siboro, dkk., 2013)

Salah satu limbah rumah tangga yang dapat dimanfaatkan sebagai pupuk organik cair yaitu limbah kulit pisang. Limbah ini banyak terdapat dikota Palu Sulawesi Tengah sebagai bahan buangan dagangan berbagai macam olahan makanan seperti pisang goreng, kripik, dan selai pisang. Limbah kulit pisang tersebut cukup banyak yaitu sekitar $1 / 3$ dari buah pisang yang belum dikupas.Sejauh ini pemanfaatan kulit pisang masih kurang, hanya sebagaian masyarakat yang memanfaatkannya sebagai pakan ternak dan cukup menarik perhatian kulit pisang terkadang hanya dibuang begitu saja di tempat sampah tanpa ada pengolahan lebih lanjut hingga lama kelamaan memberikan efek bau yang kurang sedap pada lingkungan sekitar.

Kulit pisang mengandung unsur hara yang banyak dibutuhkan tanaman, salah satunya yaitu unsur nitrogen. Nitrogen merupakan unsur penyusun yang penting dalam sintesa protein. Sebagian besar dari nitrogen total dalam air dapat terikat sebagai nitrogen organik, yaitu dalam bahan-bahan berprotein. Senyawa-senyawa nitrogen terdapat dalam bentuk terlarut atau sebagai bahan tersuspensi. Jenis nitrogen di air meliputi nitrogen organik, amonia, nitrit, dan nitrat. Perananan utama nitrogen bagi tanaman adalah untuk merangsang pertumbuhan secara keseluruhan, khusus batang, cabang, dan daun. Selain itu nitrogen pun berperan penting dalam pembentukan hijau daun yang sangat berguna dalam proses lainnya. Fungsi lainnya adalah membentuk protein, lemak, dan berbagai persenyawaan organik lainnya (Hakim, 2009)

Tulisan ini mendeskripsikan pembuatan pupuk organik cair limbah kulit pisang yang di proses melalui fermentasi sehingga dapat menentukan kadar hara nitrogen dan pengaruh pupuk organik cair limbah kulit pisang terhadap pertumbuhan tanaman kangkung darat (Ipomoea reptans poir).

\section{Metode}

\section{Alat dan Bahan :}

Alat yang digunakan: cangkul, Polybag, toples plastik, sendok, saringan santan, loyang, botol aqua, botol semprot, pisau, blender, gelas ukur, pipet tetes, timbangan biasa, timbangan analitik, alat destruksi, alat destilasi dan alat titrasi digital. Bahan yang digunakan: benih kangkung darat (Ipomea reptans poir) Bangkok LP-1, kulit pisang, tanah mengandung kotoran ternak ayam, gula pasir, air, $\mathrm{K}_{2} \mathrm{SO}_{4}$ (Merck), $\mathrm{HgO}$ (Merck), $\mathrm{H}_{2} \mathrm{SO}_{4}$ pekat (Ajak Chemicals), $\mathrm{H}_{3} \mathrm{BO}_{3}$ (Merck), Indikator metil mereh, $\mathrm{NaOH}$ (Merck), $\mathrm{HCl}$ (Smart Lab), bakteri $\mathrm{EM}_{4}$, aquades, almunium foil dan tissue.

\section{Pembuataan pupuk organik cair kulit pisang}

Limbah kulit pisang ditimbang sebanyak $5 \mathrm{~kg}$, dipotong kecil-kecil dan diblender hingga halus. Bakteri EM-4 sebanyak $125 \mathrm{~mL}$ dan gula pasir 125 $\mathrm{g}$ dilarutkan dalam toples plastik yang berisi 5 liter air kemudian diaduk hingga rata. Kulit pisang yang telah halus dicampur dalam toples plastik yang berisi cairan bakteri EM4 dan gula, kemudian diaduk kembali hingga tercampur rata dan ditutup rapat.Fermentasi dilakukan selama 8 hari (Rambitan \& Sari, 2013). Pupuk organik cair hasil dari fermentasi selama 8 hari diaduk lalu disaring kemudian dimasukkan ke dalam 7 botol aqua berukuran $1500 \mathrm{~mL}$ masing-masing sebanyak $1000 \mathrm{~mL}$.

\section{Aplikasi Pupuk Organik Cair Pada Tanaman Kangkung Darat (Ipomea reptans poir)}

Benih kangkung darat direndam dengan air hangat selama 15-20 menit. Selanjutnya masukan tanah yang mengandung kotoran ternak ayam ke dalam 8 buah polybag berukuran tinggi $25 \mathrm{~cm}$ dan diameter $20 \mathrm{~cm}$ kemudian dilubangi sedalam $1 \mathrm{~cm}$. Ambil sebanyak 3 biji benih kangkung darat ditanam ke dalam polybag yang telah dilubangi, (setiap 1 lubang berisi 1 biji benih kangkung darat) kemudian tutup kembali dengan tanah dan disiram sampai lembab. Setelah berumur 1 minggu, dilakukan pemupukan dengan perlakuan yaitu (P0 = kontrol); $(\mathrm{P} 1=20 \mathrm{~mL}) ;(\mathrm{P} 2=40 \mathrm{~mL}) ;$ dan $(\mathrm{P} 3=$ $60 \mathrm{~mL}$ ). Selanjutnya dilakukan pemeliharaan meliputi: penyulaman dilakukan pada hari ke-5 setelah tanam dengan cara menyiram tanaman kangkung darat (Ipomea reptans poir) setiap hari (pagi dan sore kecuali jika pada saat hujan). Penyiangan dilakukan untuk menghilangkan rumput-rumput liar (gulma) yang tumbuh disekitar tanaman dengan cara dicabut. Pengendalian penyakit dilakukan dengan cara mencabut tanaman yang sakit. Pengamatan dilakukan pada tinggi tanaman $(\mathrm{cm})$, jumlah daun (helai), dan berat basah (g).Panen dilakukan secara serempak pada seluruh tanaman pada umur empat minggu setelah tanam dengan mencabut seluruh bagian tanaman sampai keakarnya.

\section{Analisis kadar nitrogen total pada pupuk organik cair}

Pupuk organik cair kulit pisang sebanyak 10 $\mathrm{mL}$ dimasukkan ke dalam tabung destruksi.Kemudian ditambahkan 1,5 g campuran $\left(\mathrm{K}_{2} \mathrm{SO}_{4}\right.$ dan $\left.\mathrm{HgO}\right)$ dengan perbandingan $(1: 2)$ dan $10 \mathrm{~mL}$ larutan $\mathrm{H}_{2} \mathrm{SO}_{4}$. Semua bahan didestruksi sampai mendidih dan cairan menjadi jernih. Setelah itu pemanasan dihentikan dan 
dibiarkan sampai dingin. Setelah dingin pindahkan campuran ke dalam labu distilasi. Tabung dibilas 56 kali dengan aquades sebanyak $2 \mathrm{~mL}$ dan masukkan hasil bilasan ke dalam labu distilasi.Selanjutnya tambahkan $36 \mathrm{~mL}$ larutan $\mathrm{NaOH} 45 \%$ dan batu didih. Siapkan penampung destilat yaitu $15 \mathrm{~mL}$ larutan $\mathrm{H}_{3} \mathrm{BO}_{3} 2 \%$ dalam erlenmeyer $100 \mathrm{~mL}$ yang ditambahkan 3 tetes indikator metil merah, kemudian lakukan proses distilasi sampai destilat yang tertampung dalam erlenmeyer telah mencapai kurang lebih $25 \mathrm{~mL}$. selanjutnya distilat dititrasi dengan larutan $\mathrm{HCl}$ $0,062 \mathrm{~N}$. Hentikan proses titrasi pada saat distilat berubah warna menjadi merah muda. Lakukan hal sama pada penerapan larutan blangko dengan menggantikan sampel

dengan aquades(Bintang, 2010)

\section{Analisa Data}

Persentase nitrogen total dalam pupuk organik cair kulit pisang dihitung dengan mengunakan rumus sebagai berikut: (Bintang, 2010)

dimana $t_{s}$ : Volume titrasi sampel dan $t_{b}$ : Volume titrasi blangko

Parameter pengamatan yang dinilai meliputi tinggi tanaman $(\mathrm{cm})$, jumlah (helai) daun dan

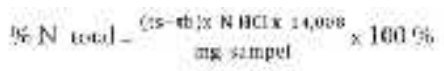

berat basah (g), untuk dianalisis dan dievaluasi menggunakan Rancangan Acak Lengkap dengan Uji Statistik Analisis Varians (Anova) dengan taraf kepercayaan $95 \%$ (Uji-F), serta jika terdapat perbedaan maka dilanjutkan dengan uji Duncan.

\section{Hasil dan Pembahasan}

\section{Produk pupuk organik cair kulit pisang}

Penelitian ini menghasilkan pupuk organik dalam bentuk cair yang dibuat dari limbah kulit pisang dan dikemas dalam botol plastik, Nasaruddin \& Rosmawati (2011) mengungkapkan bahwa pupuk organik cair (POC) yaitu pupuk organik dalam sediaan cairan unsur hara yang terkandung didalamnya berbentuk larutan yang sangat halus sehingga sangat mudah diserap oleh tanaman, sekalipun oleh bagian daun atau batangnya. Proses pembuatan pupuk organik cair limbah kulit pisang dilakukan penambahan bioaktivaktor EM4 dan gula pasir. Fungsi dari penambahan EM4 dapat membantu memecahkan nutrisi dari bahan organik sehingga dapat mempercepat proses fermentasi dan gula pasir sebagai substrat yang mudah dicerna dan dimanfaatkan untuk pertumbuhan mikroorganisme. Setelah itu, dilakukan proses fermentasi selama 1 minggu, Proses ini bertujuan menguraikan bahan organik yang dapat dimetabolime atau didegradasi oleh mikroorganisme, sehingga nutrisi yang dihasilkan dalam bentuk protein, asam amino, enzim, dan vitamin yang berguna untuk pertumbuhan
tanaman(Pangnakorn, dkk., 2010).Keberhasilan pembuatan pupuk organik cair ini ditandai dengan adanya lapisan putih pada permukaan, bau yang khas alkohol, dan warna berubah kuning kecoklatan seperti terlihat pada Gambar 1.
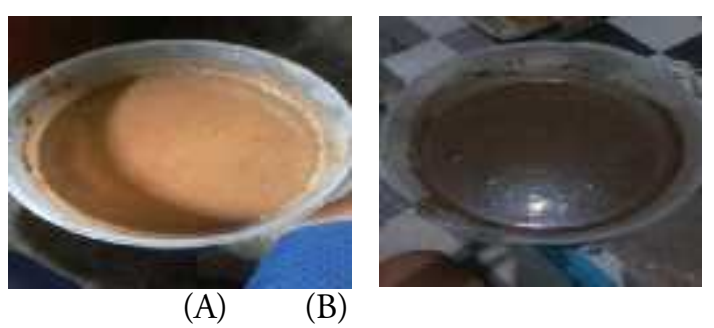

Gambar 1.sampel kulit pisang sebelum fermentasi (A) dan sesudah fermentasi (B)

Gambar 1 menunjuhkan adanya lapisan putih pada permukaan pupuk merupakan flora termofilik actinmycetes, yaitu jenis jamur tumbuh setelah terbentukya pupuk. Jamur ini berperan menguraikan bahan organik, dan lama-kelamaan proses dekomposisi ini akan berjalan lambat yang terindikasi dengan perubahan zat-zat organik kompleks menjadi cairan koloid dengan kandungan besi, kalsium dan nitrogen yang akhirnya menjadi pupuk (Latifah, dkk., 2012)

Bau khas alkohol yang dihasilkan berasal dari bakteri khamir yang dapat berperan aktif pada proses fermentasi sehingga mengubah glukosa menjadi alkohol dan perubahan alkohol menjadi asam asetat. Alkohol merupakan sumber karbon yang diperlukan untuk pertumbuhan sel sedangkan asam asetat adalah produk metabolit yang pembentukannya bergantung pada besarnya populasi bakteri asam asetat dan ketersediaan etanol. Hampir semua bahan yang mengandung alkohol, gula, pati serta adanya sejumlah kecil unsur nitrogen, dapat dibuat menjadi asam asetat (Huda, dkk., 2013). Alkohol alifatis yang sering digolongkan sebagai zat pengatur tumbuh dapat mempengaruhi metabolisme tanaman yaitu dengan jalan meningkatkan laju fotosintesis melalui peningkatan kandungan klorofil daun dan mengontrol gerak stomata (Putra \& Saefudin, 2008).

\section{Analisis kadar nitrogen total pupuk organik cair kulit pisang}

Penentuan kadar nitrogen pada penelitian ini menggunakan metode kjeldahl, terdiri dari 3 tahap yaitu destruksi, destilasi dan titrasi. Tahap Pertama terjadi penguraian sampel menjadi unsur-unsurnya yaitu $\mathrm{H}, \mathrm{O}, \mathrm{N}$, dan $\mathrm{C}$ oleh asam sulfat pekat yang bersifat oksidator kuat. Unsur karbon (C) dan hidrogen $(\mathrm{H})$ akan teroksidasi menjadi $\mathrm{CO}_{2}, \mathrm{CO}$, dan $\mathrm{H}_{2} \mathrm{O}$, sedangkan nitrogen $(\mathrm{N})$ akan berubah menjadi $\left(\mathrm{NH}_{4}\right)_{2} \mathrm{SO}_{4}$. Hasil akhirnya adalah larutan amonium sulfat. Reaksinya seperti berikut:

$\mathrm{N}$-Organik $+\mathrm{H}_{2} \mathrm{SO}_{4} \longrightarrow\left(\mathrm{NH}_{4}\right)_{2} \mathrm{SO}_{4}+\mathrm{H}_{2} \mathrm{O}+\mathrm{CO}_{2}$

Proses destruksi ini dibantu dengan penambahan katalisator yang berfungsi untuk mempercepat proses destruksi yang dimana terjadi 
kenaikan suhu berkisar pada suhu $223{ }^{\circ} \mathrm{C}-366{ }^{\circ} \mathrm{C}$ sehingga proses destruksi ini dapat berjalan cepat. Katalisator yang digunakan yaitu padatan selenium yaitu campuran dari padatan $\mathrm{K}_{2} \mathrm{SO}_{4}$ dan HgO.dimana 1 g $\mathrm{K}_{2} \mathrm{SO}_{4}$ dapat menaikan titik didih $3{ }^{\circ} \mathrm{C}$. Setelah itu proses destruksi dihentikan dan sampel menjadi jernih. Larutan yang jernih menunjukkan semua partikel bahan padat telah terdestruksi menjadi partikel yang larut tanpa partikel padat yang tersisa.

Tahap kedua yaitu tahap distilasi dimana sampel hasil destruksi ditambahkan dengan aquades.Penambahan aquades ini dilakukan agar dapat melarutkan sampel hasil destruksi agar hasilnya dapat terdistilasi dengan sempurna.Tahap distilasi ini bertujuan untuk memisahkan zat yang diinginkan yaitu memecahkan amonium sulfat $\left(\mathrm{NH}_{4}\right)_{2} \mathrm{SO}_{4}$ menjadi amonia $\left(\mathrm{NH}_{3}\right)$ dengan penambahan $\mathrm{NaOH}$. Fungsi $\mathrm{NaOH}$ yaitu dapat memberikan suasana basa karena reaksi tidak dapat berlangsung asam dan menghasilkan uap amonia yang ditangkap oleh larutan asam borak $\left(\mathrm{H}_{3} \mathrm{BO}_{3}\right)$ yang telah dicampurkan dengan indikator metil merah. Distilasi dihentikan ketika hasil destilasi berwarna kuning.

$\left(\mathrm{NH}_{4}\right)_{2} \mathrm{SO}_{4}+2 \mathrm{NaOH} \longrightarrow 2 \mathrm{Na}_{2} \mathrm{SO}_{4}+2 \mathrm{NH}_{4} \mathrm{OH}$

$2 \mathrm{NH}_{4} \mathrm{OH} \longrightarrow 2 \mathrm{NH}_{3}+2 \mathrm{H}_{2} \mathrm{O}$

$4 \mathrm{NH}_{3}+2 \mathrm{H}_{3} \mathrm{BO}_{3} \longrightarrow 2\left(\mathrm{NH}_{4}\right)_{2} \mathrm{BO}_{3}+\mathrm{H}_{2}$

Tahap terakhir yaitu tahap titrasi bertujuan untuk mengetahui berapa banyak asam borat bereaksi dengan amonia. Larutan $\mathrm{HCl}$ akan mentitrasi amonium-borat menjadi amonium klorida sehingga pada akhir titrasi terjadi kelebihan $\mathrm{HCl}$. Akhir titrasi ditandai perubahan warna larutan dari kuning berubah menjadi merah muda. Perlakuan untuk blanko juga melalui tiga tahap tersebut. Blanko berfungsi sebagai faktor koreksi terhadap senyawa $\mathrm{N}$ yang berasal dari pereaksi yang digunakan (Bintang, 2010). Hasil titrasi tersebut dapat dilihat pada Tabel 1.

Tabel 1. Kadar nitrogen total pupuk cair kulit pisang dengan mengunakan Metode Khejdal

\begin{tabular}{lllll}
\hline $\begin{array}{l}\text { Sampel } \\
\text { Pupuk } \\
\text { Organik } \\
\text { Cair Kulit }\end{array}$ & $\begin{array}{l}\text { Berat } \\
\text { Sampel } \\
(\mathrm{mg})\end{array}$ & $\begin{array}{l}\text { Volume } \\
\text { Titran } \\
(\mathrm{mL})\end{array}$ & $\begin{array}{l}\text { Volume } \\
\text { Blanko } \\
(\mathrm{mL})\end{array}$ & $\begin{array}{l}\text { Kadar } \\
\text { Nitrogen } \\
\text { Total } \\
(\%)\end{array}$ \\
\hline Ulangan 1 & 9467,1 & 4,22 & 0,22 & 0,036 \\
Ulangan 2 & 9467,0 & 3,22 & 0,22 & 0,027 \\
Ulangan 3 & 9467,1 & 3,45 & 0,22 & 0,029 \\
\hline Rata-rata & & & & 0,032 \\
\hline
\end{tabular}

Tabel 1 menunjukan rata-rata kadar nitrogen total pupuk organik cair kulit pisang yaitu sebesar 0,032\%.Kadar nitrogen total yang diperoleh merupakan hasil dari mikroba yang mampu mendekomposisi bahan organik secara keseluruhan (Saraswati \& Sumarno, 2008). Akan tetapi kadar nitrogen pada penelitian ini masih cukup rendah jika dibandingkan dengan standar minimum pupuk organik yaitu 0,4\% (Sholikah, dkk., 2013). Hal ini diduga karena pada waktu fermentasi selama 8 hari ternyata mikroorganisme sedang aktif tumbuh dan berkembang sehingga membutuhkan
$\mathrm{N}$ untuk kelangsungan hidupnya, hal ini dinamakan $\log$ phase.Log phase yaitu waktu dimana mikroorganisme mulai tumbuh dan berkembang secara logaritmis. Pada fase ini mikroorganisme mengalami perkembangbiakan yang paling cepat setelah beradaptasi terhadap kondisi baru, sel-sel akan tumbuh cepat sampai jumlah maksimum dan memakan nitrogen yang ada, sehingga kadar Nitrogen menurun (Mulyaningsih, 2013)Meskipun kadar nitrogen pada penelitian ini cukup rendah akan tetapi tidak melebihi ambang batas yang sudah ditentukan oleh Peraturan Menteri Pertanian No. 28/Permentan/OT.140/2/2009 yaitu >2\%, sehingga pupuk organik cair dapat diaplikasikan ke tanaman kangkung darat (Ipomea reptans poir).

\section{Pengaruh pupuk terhadap pertumbuhan tanaman kangkung darat (ipomea reptans poir)}

\section{Tinggi tanaman}

Berdasarkan hasil uji anava bahwa pemberian pupuk organik cair berpengaruh nyata terhadap pertumbuhan tinggi tanaman kangkung darat (Ipomea reptans Poir) diperoleh $\mathrm{F}_{\text {hitung }}(21,31)>$ $\mathrm{F}_{\text {tabel }}(6,59)$. Pertumbuhan tinggi tanaman kangkung darat (Ipomea reptans Poir) dikaitkan dengan unsur hara makro yaitu nitrogen sehingga dapat menyebabkan terdorongnya atau terpacunya sel di ujung batang untuk segera mengadakan pembelahan dan pembesaran sel terutama di daerah meristematis dan akan menyebabkan terpacunya sintesis dan pembelahan dinding sel yang didominasi pada ujung pucuk tanaman tersebut (Istiqomah, 2014). Proses ini merupakan sintesa protein yang diperoleh tanaman dari lingkungan seperti bahan organik dalam tanah. Penambahan bahan organik yang mengandung nitrogen $(\mathrm{N})$ akan mempengaruhi kadar nitrogen (N) total dan membantu mengaktifkan sel-sel tanaman dan mempertahankan jalannya proses fotosintesis yang pada akhirnya pertumbuhan tinggi tanaman dapat dipengaruhi (Hidayat, dkk., 2013).

Tabel 2 menunjukkan hasil perhitungan uji duncan dengan taraf 5\% bahwa perlakuan (P2) dengan dosis $40 \mathrm{~mL}$ menghasilkan tinggi tanaman tertinggi dengan rata-rata tinggi tanaman yaitu $23,39 \mathrm{~cm}$ berbeda nyata jika dibandingkan dengan perlakuan (P1, P3 dan P0). Hal ini diduga karena perlakuan (P2) merupakan dosis yang mampu mencukupi kebutuhan hara tanaman khususnya unsur nitrogen sehingga pertumbuhan tanaman menjadi optimal. Peranan utama nitrogen $(\mathrm{N})$ bagi tanaman untuk merangsang pertumbuhan secara keseluruhan, khususnya batang(Marviana \& Utami, 2014).

Efisiensi pemupukan yang optimal dapat dicapai apabila pupuk diberikan dalam jumlah yang sesuai kebutuhan tanaman. Bila pupuk diberikan melebihi volume tanaman adalah untuk merangsang pertumbuhan optimum, maka dapat mengakibatkan terjadinya keracunan pada tanaman (Nasaruddin \& Rosmawati, 2011) 
Perlakuan (P3) menghasilkan tinggi tanaman terendah yaitu 18,54 ( lihat Tabel 2). Hal ini disebabkan Perlakuan (P3) mengalami kelebihan unsur nitrogen sehingga pertumbuhan tidak optimal. Menurut (Zahrah, 2011) dalam pemupukan tanaman akan lebih baik bila menggunakan jenis pupuk, dosis, cara, dan waktu pemberian yang tepat. Kelebihan unsur hara seperti $\mathrm{N}$ dan unsur hara makro lainya akan berpengaruh tidak baik terhadap pertumbuhan dan produksi. Pemberian pupuk yang tidak tepat dapat mengakibatkan tanaman menjadi stres, yang menyebabkan proses fisiologi tanaman terganggu.

Tabel 2. Ringkasan uji Duncan tinggi tanaman kangkung darat (Ipomea reptans poir)

\begin{tabular}{ccc}
\multicolumn{3}{c}{ kangkung darat (Ipomea reptans poir) } \\
\hline Perlakuan & $\begin{array}{c}\text { Tinggi Tanaman } \\
(\mathrm{cm})\end{array}$ & Notasi \\
\hline P0 & 14,44 & $\mathrm{a}$ \\
P1 & 20,24 & $\mathrm{~b}$ \\
P2 & 23,39 & $\mathrm{c}$ \\
P3 & 18,65 & $\mathrm{~b}$ \\
\hline
\end{tabular}

Keterangan:

Angka yang diikuti huruf yang sama pada kolom yang sama tidak berbeda nyata menurut Uji Duncan 5\%. P0 ( Tanpa pupuk cair kulit pisang), P1 (20 mL), P2 $(40 \mathrm{~mL})$, dan P3 $(60 \mathrm{~mL})$.

\section{Jumlah daun (Helai)}

Berdasarkan hasil uji anava bahwa pemberian pupuk organik cair berpengaruh tidak nyata terhadap pertumbuhan jumlah daun kangkung darat diperoleh $\mathrm{F}_{\text {hitung }}(4,75)<\mathrm{F}_{\text {tabel }}(6,59)$. Hal ini diduga kandungan nitrogen hasil fotosintesis lebih banyakdigunakan untuk pertambahan tinggi tanaman sehingga pertumbuhan tidak berlangsung secaraseragam pada seluruh bagian tanaman.Pertumbuhan dimungkinkan terfokus padajaringan meristem batang sehinggapembesaran sel yang dihasilkan daripembelahan sel tersebut yang menyebabkan pertambahan ukuran tanaman (Kusumaningrum, dkk., 2007). Selain itu juga diduga bahwa nitrogen dalam tanah banyak dimanfaatkan oleh mikroorganisme yang terdapat pada tanah maupun pupuk sehingga terjadi persaingan kadar hara antara mikroorganisme danakar tumbuhan. Penyerapan nitrogen menjadi lebih rendah karena tidak terjadi nitrifikasi oleh bakteri yang jumlahnya menurun sehingga jumlah daun akan mengalami kerontokan (Sholikah, dkk., 2013).

Berdasarkan Tabel 3 meskipun tidak memberi pengaruh nyata secara statistik namun hasil Uji Duncan Pada taraf 5\% menunjukan bahwaperlakuan (P2) dengan dosis $40 \mathrm{~mL}$ memberi hasil jumlah daun terbanyak yaitu 9,94 helai yang tidak berbeda nyata dengan pelakuan (P1) dan (P2) namun berbeda nyata dengan (P0). Hal ini disebabkan unsur nitrogen pada perlakuan (P2) dapat mencukupi kebutuhan tanaman kangkung darat (Ipomea reptans Poir). Manfaat unsur nitrogen yaitu meningkatkan pertumbuhan tanaman, memproduksi klorofil, meningkatkan kadarprotein, dan mempercepat tumbuh daun. Klorofil dibutuhkan pada proses fotosintesis. Umumnya klorofil disintesis pada daun dan berperan untuk menangkap cahaya matahari yang jumlahnya berbeda-beda tiap spesies (Marviana $\&$ Utami, 2014). Oleh sebab itu, semakin luas permukaan daun maka intensitas sinar matahari yang diterima semakin besar, dan klorofil pada daun yang berfungsi menangkap energi matahari akan meningkatkan laju fotosentesis sehingga semakin banyak karbohidrat yang dihasilkan untuk pembelahan sel dan menyebabkan daun tumbuh lebih besar dan lebar (Uminawar, dkk., 2013) Penyerapan klorofil dapat dipengaruhioleh berbagai faktor seperti cahaya, air, suhu, unsur nitrogen dan magnesium (Gent, 2002). Sementara perlakuan (P3) mengalami pertumbuhan jumlah daun yang terendah yaitu 8,16 (helai) (lihat Tabel 3). Hal disebabkan perlakuan (P3) kekurangan (defisiensi) nitrogen pada tanaman menyebabkan pertumbuhan yang lambat dan kerdil. Daunnya berwarna hijau muda dan daun yang lebih tua menguning dan akhirnya kering (Sedayu, dkk., 2014)

Tabel 3. Ringkasan Uji Duncan jumlah daun kangkung darat (Ipomea reptans Poir)

\begin{tabular}{ccc} 
Perlakuan & $\begin{array}{c}\text { Jumlah Daun } \\
\text { (helai) }\end{array}$ & Notasi \\
\hline P0 & 7,13 & $\mathrm{a}$ \\
P1 & 8,49 & ab \\
P2 & 9,94 & $\mathrm{~b}$ \\
P3 & 8,16 & $\mathrm{ab}$ \\
\hline
\end{tabular}

\section{Keterangan:}

Angka yang diikuti huruf yang sama pada kolom yang sama tidak berbeda nyata menurut Uji Duncan 5\%.P0 (Tanpa pupuk cair kulit pisang), P1 (20 mL), P2 $(40 \mathrm{~mL})$, dan P3 $(60 \mathrm{~mL})$.

\section{Berat basah (g)}

Berdasarkan hasil uji anova bahwa pemberian pupuk organik cair berpengaruh nyata terhadap berat basah kangkung darat diperoleh $\mathrm{F}_{\text {hitung }}(9,79)$ $>\mathrm{F}_{\text {tabel }}(6,59)$. Hal ini disebabkan karena nitrogen digunakan dalam membentuk senyawa yang penting bagi proses fotosintesis dan proses pembelahan sel. Akibatnya tanaman dapat membentuk organ struktural tanaman dengan baik. Karbohidrat yang dihasilkan oleh daun sebagai hasil proses fotosintesis dapat menstimulir pembentukan organ-organ baru (Hakim, 2009). Hal tersebut diperkuat oleh pendapat (Parman, 2007) bahwa Jumlah daun yang disertai penampakan daun yang berwarna hijau menandakan adanya kandungan klorofil yang dapat menghasilkan fotosintat untuk pertumbuhan dan perkembangan tanaman yang pada akhirnya mempengaruhi berat basah tanaman.

Tabel 4 menunjukkan hasil uji duncan dengan taraf 5\% bahwa perlakuan (P2) dengan rata-rata berat basah tertinggi yaitu $27,4 \mathrm{~g}$ yang tidak berbeda nyata dengan (P1) namun berbeda nyata 
dengan (P3) dan (P0). hal ini disebabkan kandungan $\mathrm{N}$ totaltanah akan mengalami peningkatan apabila diberi pupuk organik cair, disamping itu pupuk organik cair menyebabkan pori pori tanah lebih baik, sehingga perkembangan akar menjadi lebih baik. Perkembangan akar yang baik dapat menyerap unsur hara secara maksimal (Raihan \& Tirtayani, 2001) Sementara itu, Perlakuan (P3) menghasilkan berat basah terendah yaitu 21,70 g. Hal ini disebabkan pupuk yang terlalu banyak maupun sedikit menyebabkan larutan tanah menjadi pekat sehingga air dan garam-garam mineral tidak dapat diserap oleh akar dan terjadi penimbunan garam atau ion-ion dipermukaan akar yang akan menghambat peresapan hara khususnya (N) dan sekaligus menimbulkan keracunan bagi tanaman (Supriyanto, dkk., 2014).

Tabel 4. Ringkasan Uji Duncan berat basah kangkung darat (Ipomea reptans Poir)

\begin{tabular}{ccc}
\hline Perlakuan & $\begin{array}{c}\text { Berat Basah } \\
(\mathrm{g})\end{array}$ & Notasi \\
\hline P0 & 20,10 & $\mathrm{a}$ \\
P1 & 26,10 & $\mathrm{~b}$ \\
P2 & 27,40 & $\mathrm{~b}$ \\
P3 & 21,70 & $\mathrm{a}$ \\
\hline
\end{tabular}

Keterangan:

Angka yang diikuti huruf yang sama pada kolom yang sama tidak berbeda nyata menurut Uji Duncan 5\%. P0( Tanpa pupuk cair kulit pisang), P1 (20 mL), P2 (40 mL), dan P3 (60 mL).

Berdasarkan hasil penelitian yang dilakukan dapat dikatakan bahwa dari semua parameter pertumbuhan seperti tinggi tanaman, jumlah daun dan berat basah tanaman kangkung darat (Ipomea reptans Poir) menunjukan perlakuan dengan dosis terbaik yaitu perlakuan P2 $(40 \mathrm{~mL})$ dari semua perlakuan yang dicobakan dengan rata-rata pertumbuhan tinggi tanaman yaitu $23,39 \mathrm{~cm}$, jumlah daun yaitu 9,49 helai, dan berat basah 27,40 gram, karena perlakuan tersebut lebih baik dibandingkan perlakuan lainnya. Hal ini disebabkan setiap dosis pupuk yang diberikan pada tanaman akan mempengaruhi besar kecilnya kandungan hara $\mathrm{N}$ dalam pupuk tersebut, tetapi belum dapat dijamin bahwa semakin besar dosis yang diberikan akan semakin meningkatkan pertumbuhan tanaman. Sebab tanaman juga memiliki batas dalam penyerapan hara untuk kebutuhan hidupnya (Priangga, dkk., 2013).

\section{Kesimpulan}

Kadar nitrogen total dalam pupuk organik cair kulit pisang yaitu $0,032 \%$ sedangkan pengaplikasian pupuk organik cair kulit pisang berpengaruh terhadap pertumbuhan tinggi tanaman $(\mathrm{cm})$, dan berat tanaman $(\mathrm{g})$. Namun tidak berpengaruh terhadap pertambahan jumlah daun (helai). Perlakuan P2 (40 mL) menunjukan perlakuan terbaik untuk parameter pertumbuhan tanaman kangkung darat (Ipomea reptans Poir).

\section{Ucapan Terima Kasih}

Penulis mengucapkan terima kasih kepada Idha Kusuma Utami selaku laboran laboratorium Agroteknologi FAPERTA yang telah banyak membantu selama penelitian.

\section{Referensi}

Bintang, M. (2010). Biokimia teknik penelitian. Jakarta: Erlangga.

Dewanto, F. G., Londok, J. J. M. R., Tuturoong, R. A. V. \& Kaunang, W. B. (2013). Pengaruh pemupukan anorganik dan organik terhadap produksi tanaman jangung sebagai sumber pakan. Jurnal Zootek, 32(5), 1-8.

Fahrudin, F. (2009). Budidaya caisim (brassica juncea 1.) mengunakan ekstrak teh dan pupuk kascing. Sebelas Maret, Surakarta. Retrieved from

http://eprints.uns.ac.id/9399/1/16099250820 1012411.pdf

Gent, M. P. N. (2002). Growth and compsition of salad greens as affected organic compared to nitrate fertilizer and by enviroment in high tunnels. Journal of Plant Nutrition, 25(5), 981-998.

Hakim, A. M. (2009). Asupan nitrogen dan pupuk organik cair terhadap hasil dan kadar vitamin C kelopak bunga rosela (hisbiscus sabdariffa 1.). Universitas Sebelas Maret, Surakarta. Retrieved from http://eprints.uns.ac.id/8886/1/16039250820 1009481.pdf

Hidayat, T., Wardati \& Armaini. (2013). Pertumbuhan dan produksi sawi (brassica juncea L) pada inceptiol dengan aplikasi kompos tandan kosong kelapa sawit. Jurnal Agroteknologi, 7(2), 1-9.

Huda, M. K., Latifah \& Prasetya, A. T. (2013). Pembuatan pupuk organik cair dari urin sapi dengan aditif tetes tebu (molasses) metode fermentasi. Indonesian Journal of Chemical Science, 2(3), 185-189.

Istiqomah, N. (2014). Uji penambahan pupuk organik cair terhadap pertumbuhan dan hasil tanaman kancang tanah yang dibudidayakan pada lahan lebek. Jurnal Media Sains, 7(2), 185-192.

Kusumaningrum, I., Hastuti, R. B. \& Haryanti, S. (2007). Pengaruh perasan sargassum crassifolium dengan konsentrasi yang berbeda 
terhadap pertumbuhan tanaman kedelai (glycine max (l) merill). Jurnal Buletin Anatomi dan Fisiologi, 17(2), 13-23.

Latifah, R. N., Winarsih \& Rahayu, Y. S. (2012). Pemanfaatan sampah organik sebagai bahan pupuk organik cair untuk pertumbuhan tanaman bayam merah (alternanthera ficoides). Jurnal Lentera Biologi, 1(3), 139-144.

Mahmoud, E., Kader, N. A. E.., Robin, P., Mahmoud, E., Akkal-Corfini, N. \& ElRahman, L. A. (2009). Effects of different organic and inorganic fertilizers on cucumber yield and some soil properties. Journal World of Agricultural Sciences, 5(4), 408-414.

Marviana, D. D. \& Utami, L. B. (2014). Respon pertumbuhan tanaman terung (solanum mlogena. $l$.) terhadap pemberian kompos berbahan dasar tongkol jagung dan kotoran kambing sebagai materi pelajaran biologi versi kurikulum 2013. Jurnal Penelitian Mahasiswa Pendidikan Biologi, 1(1), 161-166.

Moerhasrianto, P. (2011). Respon pertumbuhan tiga macam sayuran pada berbagai konsenrasi nutrisi larutan hidroponik. Universitas Jember, Jember. Retrieved from http://repository.unej.ac.id/bitstream/handle/1 23456789/23879/0\%20\%2861\%29.pdf?seque nce $=1$

Mulyaningsih, R. (2013). Pemanfaatan tepung tulang ayam (TTA) untuk meningkatkan kadar $N, P$, dan K pada pupuk organik cair industri limbah tahu. Semarang, Semarang. Retrieved from

http://lib.unnes.ac.id/19674/1/4311409043.p $\mathrm{df}$

Nasaruddin \& Rosmawati. (2011). Pengaruh pupuk organik cair (POC) hasil fermentasi daun gamal, batang pisang dan sabut kelapa terhadap pertumbuhan bibit kakao. Jurnal Agrisistem, 7(1), 29-37.

Ohorella, Z. (2012). Pengaruh dosis pupuk organik cair (POC) kotoran sapi terhadap pertumbuhan dan produksi tanaman sawi hijau (brassica sinensis 1.). Jurnal Agroforestri, 8(1), 43-48.

Pangnakorn, U., Watanasorn, S., Kuntha, C. \& Chuenchooklin, S. (2010). Effects wood vinegar and fermented liquid organic fertilizer on soybean (srisamrong 1) cultivanted under drought condition. Journal International
Society For Southeast Asian Agricultural Sciences, 16(2), 67-63.

Parman, S. (2007). Pengaruh pemberian pupuk organik cair terhadap pertumbuhan dan produksi kentang (solanum tuberosum l.). Jurnal Buletin Anatomi dan Fisiologi, 17(2), 21-31.

Priangga, R., Suwarno \& Hidayat, N. (2013). Pengaruh level pupuk organik cair terhadap produksi bahan kering dan imbangan daunbatang rumput gajah defeliosi keempat. Jurnal Ilmiah Peternakan, 1(1), 365-373.

Putra, Y. W. \& Saefudin, N. (2008). Alkohol alifatis sebagai pemacu pertumbuhan dan prekursor dasar dari ethylen melalui jalur sintesa HMP (high metabolism pathway). Jurnal Primadona,, 4(1), 84-90.

Raihan \& Tirtayani, N. (2001). Pengaruh pemberian bahan organik terhadap $\mathrm{N}$ dan $\mathrm{P}$ tersedia tanah serta hasil beberapa varietas jagung di lahan pasang surut. Jurnal Agrivita, 23(1), 13-19.

Rambitan, V. M. M. \& Sari, M. P. (2013). Pengaruh pupuk kompos kulit pisang kepok (musa paradisiaca l.) terhadap pertumbuhan dan hasil tanaman kacang tanah (arachis hypogaea l.) sebagai penunjang praktikum fisiologi Tumbuhan. Jurnal Education Biologi Tropika, 1(1), 1-60.

Saraswati, R. \& Sumarno. (2008). Pemanfaatan mikroba penyubur tanah sebagai komponen teknologi pertanian. Jurnal Iptek Tanaman Pangan, 3(1), 41-58.

Sedayu, B. B., Erawan, I. M. S. \& Assadad, L. (2014). Pupuk cair dari rumput laut eucheuma cottonii, sargassum sp. dan gacilaria $s p$. mengunakan proses pengomposan. Jurnal Pascapanen Bioteknologi Kelautan dan Perikanan, 9(1), 61-68.

Sholikah, M. H., Suyono \& Wikandari, P. R. (2013). Efektivitas kandungan unsur hara $\mathrm{N}$ pada pupuk kandang hasil fermentasi kotoran ayam terhadap pertumbuhan tanaman terung. Journal UNESA of Chemistry, 2(1), 131-136.

Siboro, E. S., Surya, E. \& Herlina, N. (2013). Pembuatan pupuk cair dan biogas dari campuran limbah sayuran. Jurnal Teknik Kimia, 2(3), 40-43. 
Supriyanto, Muslimin \& Umar, H. (2014). Pengaruh berbagai dosis pupuk organik cair urin sapi terhadap pertumbuhan semai jambon merah. Jurnal Warta Rimba, 2(2), 149-157.

Taufika, R., Chaniago, I. \& Ardi. (2011). Pengujian beberapa dosis pupuk organik cair terhadap pertumbuhan dan hasil tanaman wortel (daucus carota l.). Jurnal Tanaman Hortikultura, 4(3), 175-184.

Uminawar, Umar, H. \& Rahmawati. (2013). Pertumbuhan semai nyatoh (palaquium sp.) pada berbagai perbandingan media dan konsentrasi pupuk organik cair di persemaian. Jurnal Warta Rimba, 1(1), 1-9.
Wijaya, T. A., Djauhari, S. \& Cholil, A. (2014). Keanekaragaman jamur filoplarn kangkung darat (ipomoea reptans poir.) pada lahan pertanian organik dan konvensional. Jurnal Hama Penyakit Tumbuhan, 2(1), 29-36.

Zahrah, S. (2011). Respons berbagai varietas kedelai (glycine max (l) merril) terhadap pemberian pupuk NPK organik. Jurnal Teknobiologi, 2(1), 65-69. 